\author{
Adam Zaremba \\ Uniwersytet Ekonomiczny w Poznaniu \\ e-mail: adam.zaremba@ue.poznan.pl
}

\title{
NIEDOSZACOWANIE CENY EMISYJNEJ OBLIGACJI NA RYNKU CATALYST
}

\begin{abstract}
Streszczenie: Anomalie związane z debiutami obligacji korporacyjnych są względnie słabo rozpoznanym obszarem w literaturze naukowej, któremu poświęcono wyraźnie mniejszą uwagę niż IPO na rynkach akcji. Nieliczne badania dotyczące rynku amerykańskiego sugerują występowanie niedoszacowania ceny emisyjnej obligacji przedsiębiorstw. Niniejszy artykuł jest bodaj pierwszą próbą zweryfikowania, czy podobne zjawisko występuje również w Polsce, a także odpowiedzi na pytanie, jakie czynniki wpływają na jego kształtowanie. Badanie wykorzystuje narzędzia analizy zdarzeń oraz regresji. Obliczenia oparte zostały na wyselekcjonowanej próbie 142 polskich papierów komercyjnych emitowanych w okresie maj 2010-sierpień 2013. Przeprowadzone obliczenia pozwoliły potwierdzić występowanie na rynku polskim efektu niedoszacowania ceny emisyjnej dłużnych papierów korporacyjnych. Niemniej wskazanie czynników, które decydują o skali niedoszacowania, okazało się niemożliwe.
\end{abstract}

Słowa kluczowe: obligacje przedsiębiorstw, niedoszacowanie ceny emisyjnej, IPO, efektywność rynku finansowego, Catalyst.

DOI: $10.15611 /$ nof.2014.3.08

\section{Wstęp}

Anomalie związane z giełdowymi debiutami na rynkach akcji doczekały się już pokaźnej literatury naukowej. Badania na całym świecie dokumentowały zarówno efekty krótkoterminowe, związane z początkowym niedowartościowaniem, jak i długoterminowe anomalie, dotyczące niskich stóp zwrotu. Wokół obu zjawisk narosło wiele hipotez starających się objaśnić ich postawanie ${ }^{1}$. Wobec tak dużej uwagi poświęcanej rynkom akcji zaskakiwać może fakt, że niewiele badań dotyczyło analogicznych zjawisk na rynku obligacji korporacyjnych. Do tej pory przeprowadzono niewiele badań dotyczących anomalii związanych z debiutami papierów dłużnych

\footnotetext{
${ }^{1}$ Zestawienia badań dotyczących debiutów na międzynarodowych rynkach akcji można znaleźć na przykład w pracach Rittera [1998] oraz Jenkinsona i Ljungqvista [2001], natomiast w zakresie rynku polskiego i regionu CEE u Zaremby i Kamińskiego [2011] lub Zaremby i Szyszki [2014].
} 
w Stanach Zjednoczonych oraz zaledwie kilka dotyczących innych rynków zagranicznych. Co więcej, jak dotychczas - zgodnie z wiedzą autora - żadne badanie dotyczące wspomnianego zagadnienia nie koncentrowało się na rynku polskim.

Cele niniejszego artykułu to zbadanie, czy zjawisko początkowego niedoszacowania dłużnych papierów wartościowych podczas debiutu funkcjonuje na polskim rynku obligacji korporacyjnych, a także próba wskazania, jakie czynniki decydują o skali tego niedoszacowania. Artykuł składa się z pięciu części, z których pierwsza stanowi niniejszy wstęp. Część druga zawiera przegląd dotychczasowej literatury przedmiotu, w tym w szczególności hipotez tłumaczących niedoszacowanie podczas debiutów oraz badań empirycznych w tym zakresie. Część trzecia prezentuje przyjętą metodologię badawczą, natomiast w części czwartej omówione zostały wyniki badań. Obliczenia oparte zostały na wyselekcjonowanej próbie 142 polskich papierów komercyjnych, które emitowane były w okresie maj 2010-sierpień 2013. Artykuł kończy podsumowanie, zawierające wnioski i sugestie dalszych badań.

Niniejszy tekst ma za cel poszerzyć aktualny stan wiedzy w dwóch aspektach - po pierwsze: zweryfikować, czy niedoszacowanie obligacji przedsiębiorstw podczas debiutów występuje w Polsce; po drugie: określić, jakie czynniki powodują nasilenie lub zminimalizowanie jego skali. Wyniki badań będą istotne dla różnych uczestników rynku finansowego. Z punktu widzenia emitentów obligacji pozwolą lepiej oszacować koszt kapitału na rynku obligacji wraz z jego składowymi, a także pomogą zrozumieć, jak można go zminimalizować. $Z$ kolei inwestorom umożliwią dokładniejsze prognozowanie stóp zwrotu na rynku obligacji korporacyjnych².

\section{Podstawy teoretyczne}

Istnieje duża liczba hipotez dotyczących zjawiska początkowego niedoszacowania akcji na debiucie, jednak tylko część z nich ma zastosowanie w zakresie obligacji przedsiębiorstw. W praktyce występują dwa standardowe wythumaczenia: zjawisko asymetrii informacyjnej pomiędzy inwestorami i emitentami oraz nadmierna konkurencja wśród organizatorów emisji.

Model asymetrii informacyjnej może przybierać kilka form, które w niewielkim stopniu różnią się od siebie, jednak w każdym przypadku opiera się na niejednakowym dostępie do informacji poszczególnych uczestników rynku. Rock [1986] zauważa, że na rynku może mieć miejsce sytuacja, gdzie dobrze poinformowani inwestorzy będą inwestować jedynie w poprawnie lub niskowycenione IBO (Initial Bond Offering - pierwsza emisja obligacji), zostawiając inwestycje w przeszacowane i niezbyt zyskowne IBO dla gorzej poinformowanych inwestorów. Problem ten zostaje rozwiązany przez niedoszacowanie „kiepskich” emisji, które w innym wypadku mogłyby nie wzbudzić zainteresowania nabywców. Z kolei Benveniste i Spindt [1989] rozwijają model Rocka w ten sposób, że wskazują, że organizato-

\footnotetext{
${ }^{2}$ Wyniki niniejszego badania zaprezentowano również w pracy Zaremby [2014].
} 
rzy emisji mogą dzięki niedoszacowaniu informację wydobyć od poinformowanych inwestorów na temat ich wyceny papieru wartościowego. Innymi słowy, zgodnie z tym podejściem, opisywanym także przez Benveniste, Busabę i Wilhelma [2002] oraz Shermana i Titmana [2002], niedoszacowanie stanowi formę zapłaty za informację o wycenie ze strony inwestorów.

Dalsze rozwinięcie teorii asymetrii informacyjnych koncentruje się przede wszystkim na różnicy w dostępie do informacji pomiędzy zarządami spółek a inwestorami [Allen, Faulhaber 1989; Welch 1989; Grinblatt, Hwang 1989] . Zarządy wiedzą na temat spółki więcej aniżeli inwestorzy, więc mogą ukrywać niekorzystne informacje. Inwestor, oczywiście, nie wie, która spółka jest „dobra”, a która „zła”, więc musi zakładać, że w każdym przypadku spółka jest „zła”. W dodatku inwestor jest świadom, że „dobrym” spółkom w zasadzie nie opłaca się robić emisji, ponieważ i tak zostaną wycenione tak jak ,złe”. Tym samym dyskonto w wycenie (czyli początkowe niedoszacowanie) stanowi pewną rekompensatę dla inwestorów, mającą ich zachęcić do inwestycji pomimo ryzyka związanego z asymetrią informacyjną. Część autorów sugeruje, że problem asymetrii informacyjnej może być zredukowany dzięki dobrej reputacji emitenta lub organizatora emisji [Chemmanur, Paeglis 2005; Chemmanur, Fulghieri 1994; Hughes, Thakor 1992; Diamond 1989; 1991; Gorton 1996; Fenn 2000; Carty 1996].

Datta, Iskandar-Datta i Patel [1997] sugerują, że błędna wycena obligacji przedsiębiorstw podczas debiutu może być rezultatem konkurencji cenowej pomiędzy organizatorami emisji. Zgodnie z ich hipotezą organizatorzy chętnie konkurują przede wszystkim o emisje wysokiej jakości (o wysokim ratingu, najczęściej inwestycyjnym), co odbywa się kosztem emisji gorszych jakościowo, mających rating śmieciowy, lub też takich, którym w ogóle nie nadano ratingu. Do tego w analogiczny sposób dołączają działania gwarantów emisji, generujących dodatkowy popyt na wysokojakościowe obligacje. Ponieważ konkurencja odbywa się na poziomie cenowym (oznacza to, że organizatorzy konkurują w tym, któremu uda się najdrożej sprzedać papiery), w rezultacie można wydedukować, że emisje o wysokim ratingu są sprzedawane po przesadnie wysokich cenach (są przeszacowane), natomiast papiery o niskiej jakości, które nie przyciągają uwagi organizatorów emisji, są sprzedawane po cenach zbyt niskich (są niedoszacowane).

Hipoteza konkurencji zdaje się mieć dwa istotne słabe punkty: po pierwsze, trudno wyjaśnić, dlaczego inwestorzy akceptują inwestycje w emisje, które są przewartościowane; po drugie, nie bierze ona w pełni pod uwagę innych pól, na których organizatorzy emisji mogą ze sobą konkurować.

Hipotezę konkurencji zdają się potwierdzać między innymi badania, które przeprowadzili Datta, Iskandar-Datta i Patel [1997], wskazujące ujemne ponadprzeciętne stopy zwrotu podczas debiutów obligacji o wysokim ratingu oraz dodatnie w zakresie obligacji o niskim ratingu. Potwierdzają ją także wyniki uzyskane przez takich badaczy, jak Kelly, Helwege i Warga [2007], choć warto również odnotować, że McKenzie 
i Takaoka [2008] dochodzą do całkowicie przeciwnych wniosków. Rozwinięcia modelu konkurencji można znaleźć także w pracy [Takaoka, McKenzie 2006].

Oprócz wspomnianych teorii, warto także odnotować próby wyjaśnienia zachowania obligacji po debiucie za pomocą zjawisk związanych z płynnością. Dotychczas w tym obszarze badań dochodzono jednak do odmiennych wniosków. Ellul i Pagano [2006] uważają, że niedoszacowanie może być wynagrodzeniem za niską płynność papierów po debiucie, co po części udaje im się potwierdzić empirycznie. Z kolei Booth i Chua [1996] są zdania, że początkowe niedoszacowanie skutkuje potem wzmożoną aktywnością inwestorów po debiucie. Warto także zwrócić uwagę na pracę [McKenzie, Takaoka 2008], której autorzy wiążą poziom niedoszacowania IBO ze zmiennością rynku akcji i stóp procentowych.

Badania empiryczne nad ponadprzeciętnymi stopami zwrotu podczas debiutów przyjmowały historycznie dwie formy: bądź to analizy rentowności obligacji, bądź też zachowania ich cen. Wczesne badania [Ederington 1974; Lindvall 1977; Sorensen 1982] koncentrowały się na rentownościach w okresie do wykupu (YTM) debiutujących obligacji i wskazywały, że są one zwykle wyższe niż w przypadku już notowanych obligacji o zbliżonym ratingu kredytowym i zapadalności. W związku z problemami związanymi z kalkulacją YTM, na którą wpływają między innymi wbudowane w obligacje opcje, Weinstein [1978] zdecydował się oprzeć badanie na zmianach cen skorygowanych o zmiany właściwego benchmarku. Weinstein bazował na próbie 179 pierwszych emisji obligacji [IBO] i 412 kolejnych emisjach obligacji (SBO, Secondary Bond Offering - kolejna emisja obligacji) z lat 1962-1974. Niemal wszystkie obligacje w próbie miały rating inwestycyjny. Autor odnotował ponadprzeciętną stopę zwrotu na poziomie $0,366 \% \mathrm{w}$ pierwszym miesiącu notowań. Z kolei takim badaczom, jak Fung i Rudd [1986], nie udało się potwierdzić funkcjonowania efektu niedoszacowania podczas debiutów, natomiast Wasserfallen i Wydler [1988] znaleźli dowody na jego istnienie na rynku szwajcarskim.

Starsze badania nie rozróżniały analizy na IBO i SBO. Luka ta została bodaj po raz pierwszy wypełniona przez zespół autorski w składzie: Datta, Iskandar-Datta i Patel [1997]. Badacze ci, wykorzystując notowania z NYSE, wyliczyli dodatnie ponadprzeciętne stopy zwrotu podczas debiutu na poziomie $1,86 \%$ dla obligacji śmieciowych (subinwestycyjnych) oraz ujemne dla obligacji inwestycyjnych. Podobną metodologią posłużyli się Helwege i Kleiman [1998], jednak wykorzystali oni kwotowania dealerów obligacji, które były, ich zdaniem, bardziej reprezentatywne dla rynku dłużnego, ma on bowiem w dużej mierze charakter niepubliczny. Autorzy dostrzegli istotne statystycznie niedoszacowanie nowych obligacji śmieciowych, jednak sięgające jedynie 39 punktów bazowych.

Wśród nowszych prac nad IBO, należy wskazać teksty Kozhanova i Ogdena [2012] i Kelly, Helwege i Warga [2007], które ogólnie potwierdzają efekt niedoszacowania, a także artykuł [McKenzie, Takaoka 2008], który wskazuje, że na rynku japońskim regułą było raczej przeszacowanie niż niedoszacowanie. Na uwagę zasługuje także artykuł [Kozhanov, Ogden i Vaghefi 2011], wskazujący, że obligacje kor- 
poracyjne najpierw - natychmiast po debiucie - generują dodatnie ponadprzeciętne stopy zwrotu, które utrzymują się nawet do pół roku, jednak w późniejszym okresie ceny wykazują tendencję spadkową, niwelując tym samym początkowe ponadprzeciętne zyski.

\section{3. Źródła danych i metody badawcze}

Na potrzeby niniejszego badania wzięto pod uwagę wszystkie obligacje notowane na rynku Catalyst, których emisje odbyły się w okresie marzec 2010-sierpień 2013. $\mathrm{Z}$ próby wyeliminowano obligacje zerokuponowe (ze względu na znacząco odmienny przebieg notowań), obligacje Banku Gospodarstwa Krajowego (ze względu na charakter zbliżony do obligacji skarbowych oraz obligacje, w przypadku których pierwsza transakcje miała miejsce później niż 100 dni od debiutu (w celu wyeliminowania zaburzenia wyników badań przez instrumenty skrajnie niepłynne). Po przeprowadzeniu opisanej selekcji ostateczna próba zawierała 142 emisje obligacji korporacyjnych. Dane w zakresie notowań, dat i cen emisji oraz wartości benchmarków pochodziły z serwisu Bloomberg.

Badania zachowania obligacji przedsiębiorstw po debiucie dokonano w sposób następujący. W pierwszej kolejności przeprowadzono analizę zdarzeń, licząc przeciętne skumulowane anormalne stopy (Average Cumulative Abnormal Returns ACAR). Jest to metoda najbardziej popularna wśród badaczy, choć budząca pewne kontrowersje metodologiczne, zwłaszcza w przypadku analizy długookresowej reakcji rynku na wydarzenia [Fama 1998]. Następnie, wykorzystując obliczone wcześniej ACAR, wykonano analizę regresji z użyciem zmiennych jakościowych.

Pomiar ACAR rozpoczęto przez obliczenie anormalnych stóp zwrotu (Abnormal Returns - ARs) na każdy dzień w 180-dniowym okresie obserwacji. Dzienne AR kalkulowane były jako:

$$
A R_{i t}=R_{i t}-R_{E(i, t)},
$$

gdzie $R_{i t}$ oznacza stopę zwrotu ${ }^{3} i$ w dniu $t$, natomiast $R_{E(i, t)}$ - oczekiwaną stopę zwrotu $\mathrm{z}$ obligacji $i \mathrm{w}$ dniu $t$.

Literatura ekonometryczna proponuje dużą liczbę modeli oczekiwanych stóp zwrotu, które w ostatnich latach stają się coraz bardziej wyrafinowane i skomplikowane. Interesujące przeglądy modeli można znaleźć np. w opracowaniach [Campbell, Lo, MacKinlay 1996; MacKinlay 1997; Kothari, Warner 1997; 2006]. W niniejszym tekście wykorzystano podejście stosowane wcześniej między innymi przez takich autorów, jak: Datta, Iskandar-Datta, Patel [1997] oraz Kelly, Helwege i Warga [2007], polegające na wykorzystaniu stop zwrotu skorygowanych o stosowny

\footnotetext{
${ }^{3}$ We wszystkich obliczeniach wykorzystaliśmy logarytmiczne stopy zwrotu i ceny „czyste” (bez narosłych odsetek).
} 
benchmark. $\mathrm{Z}$ formalnego punktu widzenia była to wariacja klasycznego modelu rynkowego (market model), zgodnie z definicją MacKinlaya [1997].

$$
\begin{aligned}
& R_{i t}=\alpha_{i t}+\beta_{i} R_{m t}+\varepsilon_{i t}, \\
& E\left(\varepsilon_{i t 0}\right)=0, \operatorname{var}\left(\varepsilon_{i t 0}\right)=\sigma_{s}^{2},
\end{aligned}
$$

gdzie $R_{i t}$ oraz $R_{m t}$ to stopy zwrotu w okresie $t$ z obligacji $i$ i portfela benchmarkowego, $\varepsilon_{i t}$ to składnik losowy o średniej równej zeru, natomiast $\alpha_{i}$, oraz $\sigma_{s}^{2}$ to parametry modelu.

Wykorzystany przez nas skorygowany model rynkowy [MacKinlay 1997] odbiega od klasycznego modelu o tyle, że wartość parametru $\alpha_{i}$ jest przyjęta a priori na poziomie 0 , natomiast parametru $\beta_{i}$ na poziomie 1 .

$\mathrm{W}$ rezultacie specyfikacja modelu przedstawia się tak, jak to zaprezentowano we wzorze (3).

$$
R_{i t}=R_{m t} \text {. }
$$

Jako portfele benchmarkowe wykorzystane zostały dobierane zapadalnością indeksy Bloomberg/EFFAS Polish Goverment Bond Price Index ${ }^{4}$. Autor zdaje sobie sprawę, że bardziej poprawne byłoby wykorzystanie indeksów obligacji korporacyjnych, których zachowanie uwzględniałoby nie tylko wahania rynkowych stóp procentowych, ale także zmiany w wycenie ryzyka kredytowego, jednak na polskim rynku nie są dotychczas dostępne żadne indeksy tego typu.

W tym miejscu należy podkreślić, że pierwsza $A R_{i t}$ liczona była względem ceny emisyjnej za cały okres od dnia emisji do dnia pierwszej sesji transakcyjnej, a także, że odnosiła się do zachowania benchmarku również w tym okresie.

Po wyznaczeniu dziennych AR na podstawie modeli oczekiwanych stóp zwrotu w kolejnym kroku dokonano kumulacji w czasie, wyznaczając skumulowane anormalne stopy zwrotu (Cumulative Abnormal Returns - CARs):

$$
C A R_{i t}=\sum_{t=1}^{T} A R_{i t},
$$

po czym następnie je uśredniono dla wszystkich spółek w próbie, uzyskując przeciętne skumulowane anormalne stopy zwrotu (Average Cumulative Abnormal Returns - ACARs):

$$
A C A R=\sum_{i=1}^{N} C A R_{i},
$$

Kalkulując stopy ACAR, próbę dodatkowo podzielono na podgrupy ze względu na istotne charakterystyki obligacji lub emitenta, które mogłyby wpływać na skalę

${ }^{4}$ Bloomberg/EFFAS Polish Goverment Bond Price Index to cenowy indeks (nieuwzględniający narosłych odsetek) polskich obligacji skarbowych, liczony w pięciu wariantach dla obligacji o różnej zapadalności: 1-3, 3-5, 5-7, 7-10 oraz 10+. 
ponadprzeciętnych stóp zwrotu: zapadalność obligacji, ich zabezpieczenie, wcześniejsze notowanie akcji na giełdzie, wielkość emisji oraz jej charakter (IBO lub SBO).

Hipoteza zerowa, która zakłada, że stopy ACAR nie są statystycznie istotnie różne od zera, została w toku badania skonfrontowana $\mathrm{z}$ hipotezą alternatywną, mówiącą, że ACAR różnią się jednak od zera. Istotność statystyczną zweryfikowano za pomocą klasycznych metod parametrycznych.

W dalszej kolejności, wykorzystując stopy zwrotu CAR, dla pierwszej sesji transakcyjnej po debiucie, przeprowadzono analizę regresji przy użyciu zmiennych ilościowych. Analiza regresji miała na celu zbadanie wpływu szeregu czynników na ponadprzeciętne stopy zwrotu na debiucie i brała pod uwagę te same zmienne zero-jedynkowe, które wcześniej służyły do podziału ACAR na podgrupy:

1. IPO - pierwsza emisja obligacji danej spółki.

2. Spółka niepubliczna - akcje spółki nie były notowane na rynku regulowanym w dniu emisji obligacji.

3. Brak zabezpieczenia - obligacje zostały wyemitowane jako niezabezpieczone.

4. Mała emisja - łączna wartość emisji obligacji nie była wyższa niż 10 milionów zł.

5. Obligacja długoterminowa - zapadalność obligacji przekraczała 3 lata.

Analiza regresji została wykonana dla ośmiu odrębnych konfiguracji powyższych zmiennych przy użyciu KMNK.

\section{Rezultaty badań}

Rysunek 1 prezentuje skumulowane stopy ACAR w ciągu 180 dni od pierwszej sesji transakcyjnej.

Zachowanie cen powiela schematy, które dostrzeżono w analogicznych badaniach dla rynku amerykańskiego w segmencie papierów o ratingu subinwestycyjnym. W ciągu w przybliżeniu pierwszych dwóch miesięcy notowań obligacje przynosiły ponadprzeciętne stopy zwrotu, sięgające niemal 1\%. Następnie, w kolejnych miesiącach, stopy te były niwelowane, by między 4 a 6 miesiącem obniżyć się do 0 lub wręcz przyjąć znak ujemny. Jak jednak wskazuje tab. 1, o ile początkowe ponadprzeciętne stopy zwrotu były statystycznie istotnie różne od zera, o tyle późniejsze ujemne stopy ACAR nie cechowały się już istotnością statystyczną.

Stopy zwrotu zarówno z IBO, jak i SPO były istotnie wyższe od zera i utrzymywały się jeszcze przez 60 dni notowań. Co ciekawe, stopy zwrotu z IBO nie były wyższe, a wręcz niższe od stóp z SBO. Jest to obserwacja odwrotna niż spostrzeżenia dotychczas poczynione na rynku amerykańskim. Po 90 dniu nie można już stwierdzić, że stopy zwrotu są wciąż istotnie różne od zera, po 150 dniu stawały się wręcz ujemne, jednak obserwacji tej brak jest istotności statystycznej.

Tabela 2 prezentuje stopy ACAR dla pierwszej sesji transakcyjnej w ramach poszczególnych podgrup pełnej próby. 


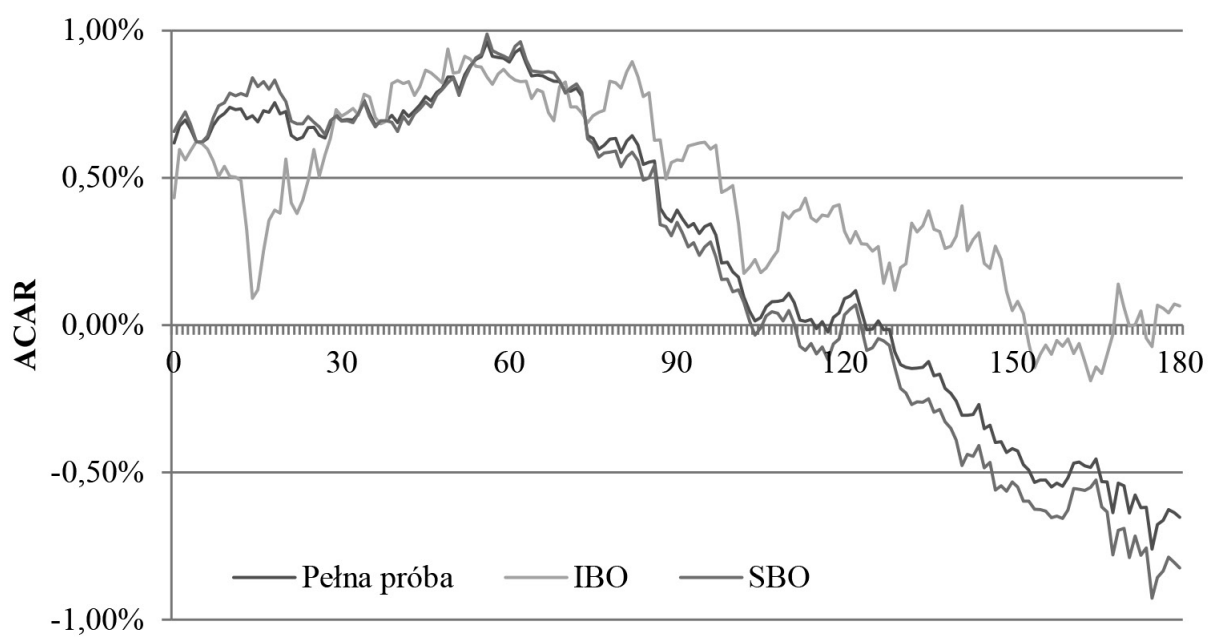

Dni od pierwszej transakcji

Rys. 1. Stopy ACAR w ciągu 180 dni od pierwszej sesji transakcyjnej

Źródło: opracowanie własne.

Tabela 1. Stopy ACAR dla IBO i SBO

\begin{tabular}{|c|c|c|c|c|c|c|c|c|c|}
\hline \multirow{2}{*}{$\begin{array}{l}\text { Numer } \\
\text { dnia } \\
\text { notowań }\end{array}$} & \multicolumn{3}{|c|}{ Pełna próba } & \multicolumn{3}{|c|}{ IBO } & \multicolumn{3}{|c|}{ SBO } \\
\hline & $\begin{array}{c}\mathrm{ACAR} \\
{[\%]}\end{array}$ & t-stat & $\begin{array}{c}\text { liczba } \\
\text { obserwacji }\end{array}$ & $\begin{array}{c}\text { ACAR } \\
{[\%]}\end{array}$ & $t$-stat & $\begin{array}{c}\text { liczba } \\
\text { obserwacji }\end{array}$ & $\begin{array}{c}\mathrm{ACAR} \\
{[\%]}\end{array}$ & t-stat & $\begin{array}{c}\text { liczba } \\
\text { obserwacji }\end{array}$ \\
\hline 1 & $0,619 * * *$ & $3,783 * * *$ & 142 & $0,432 * *$ & $2,005 * *$ & 24 & $0,656 * * *$ & $3,414 * * *$ & 118 \\
\hline 2 & $0,675 * * *$ & $4,139 * * *$ & 142 & $0,597 * * *$ & $2,767 * * *$ & 24 & $0,691 * * *$ & $3,601 * * *$ & 118 \\
\hline 3 & $0,696 * * *$ & $4,198 * * *$ & 142 & $0,561 * * *$ & $2,588 * * *$ & 24 & $0,723 * * *$ & $3,707 * * *$ & 118 \\
\hline 10 & $0,718 * * *$ & $3,969 * * *$ & 141 & 0,538 & 1,583 & 24 & $0,755^{*} * *$ & $3,638 * * *$ & 117 \\
\hline 30 & $0,713 * * *$ & $3,909 * * *$ & 136 & $0,732 * *$ & $1,986 * *$ & 24 & $0,709 * * *$ & $3,404 * * *$ & 112 \\
\hline 60 & $0,906 * * *$ & $3,57 * * *$ & 130 & $0,869^{*}$ & $1,907 *$ & 23 & $0,914 * * *$ & $3,108 * * *$ & 107 \\
\hline 90 & 0,351 & 1,531 & 118 & 0,551 & 1,250 & 23 & 0,303 & 1,138 & 95 \\
\hline 150 & $-0,432$ & $-1,313$ & 103 & 0,114 & 0,275 & 20 & $-0,563$ & $-1,421$ & 83 \\
\hline 180 & $-0,636$ & $-1,461$ & 98 & 0,071 & 0,159 & 19 & $-0,806$ & $-1,522$ & 79 \\
\hline
\end{tabular}

* Statystycznie różne od 0 na poziomie $10 \%$, ** statystycznie różne od 0 na poziomie $5 \%$, *** statystycznie różne od 0 na poziomie $1 \%$.

Źródło: opracowanie własne.

Analizując tab. 2, trudno na pierwszy rzut oka wskazać zmienne, które decydują o skali ponadprzeciętnych stóp zwrotu podczas debiutu. Żaden z czynników opisanych w dotychczas dostępnej literaturze przedmiotu nie wydaje się kluczowy dla powstawania efektu niedoszacowania. Obserwacje te potwierdzają również przedstawione w tab. 3 wyniki analizy regresji. 
Tabela 2. Stopy ACAR w podgrupach pełnej próby

\begin{tabular}{|c|c|c|c|c|}
\hline & $\operatorname{ACAR}[\%]$ & $\begin{array}{c}\text { Liczba } \\
\text { obserwacji }\end{array}$ & $\begin{array}{c}\text { Udział } \\
\text { w próbie } \\
(\%)\end{array}$ & $t$-stat \\
\hline \multicolumn{5}{|c|}{ Panel 1: notowania na giełdzie } \\
\hline Spółki nienotowane na giełdzie & 0,308 & 54 & 38,03 & 1,075 \\
\hline Spółki notowane na giełdzie & $0,809 * * *$ & 88 & 61,97 & $4,117 * * *$ \\
\hline \multicolumn{5}{|c|}{ Panel 2: zapadalność obligacji } \\
\hline Obligacje krótkoterminowe (do 3 lat włącznie & $0,677 * * *$ & 92 & 64,79 & $4,725 * * *$ \\
\hline Obligacje długoterminowe (powyżej 3 lat) & 0,510 & 50 & 35,21 & 1,317 \\
\hline \multicolumn{5}{|c|}{ Panel 3: wielkość emisji } \\
\hline Małe emisje (do 10 mln zł włącznie) & $0,396 * *$ & 64 & 45,07 & $2,055^{* *}$ \\
\hline 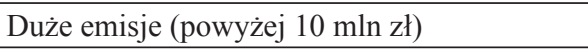 & $0,801 * * *$ & 78 & 54,93 & $3,171 * * *$ \\
\hline \multicolumn{5}{|c|}{ Panel 4: zabezpieczenie emisji } \\
\hline Emisje niezabezpieczone & $0,634 * * *$ & 128 & 90,14 & $3,539 * * *$ \\
\hline Emisje zabezpieczone & 0,475 & 14 & 9,86 & 1,700 \\
\hline \multicolumn{5}{|c|}{ Panel 5: numer emisji obligacji } \\
\hline IPO - pierwsza emisja obligacji & $0,432 * *$ & 24 & 16,90 & $2,005 * *$ \\
\hline SPO - kolejna emisja obligacji & $0,656 * * *$ & 118 & 83,10 & $3,414 * * *$ \\
\hline
\end{tabular}

* Statystycznie różne od 0 na poziomie $10 \%$, ** statystycznie różne od 0 na poziomie 5\%, *** statystycznie różne od 0 na poziomie $1 \%$.

Źródło: opracowanie własne.

Tabela 3. Wyniki analizy regresji wielorakiej

\begin{tabular}{|c|c|c|c|c|c|c|c|c|}
\hline Zmienne & (1) & (2) & (3) & (4) & (5) & (6) & (7) & (8) \\
\hline \multirow{2}{*}{ Wyraz wolny (\%) } & $0,656^{* * *}$ & $0,806 * * *$ & 0,475 & $0,801 * * *$ & $0,677 * * *$ & $0,831 * * *$ & 0,652 & 0,787 \\
\hline & $3,663 * * *$ & $3,930 * * *$ & 0,912 & $3,650 * * *$ & $3,337 * * *$ & $3,861 * * *$ & 1,228 & 1,405 \\
\hline \multirow{2}{*}{ IPO (\%) } & $-0,224$ & & & & & $-0,174$ & & $-0,243$ \\
\hline & $-0,514$ & & & & & $-0,399$ & & $-0,524$ \\
\hline \multirow{2}{*}{$\begin{array}{l}\text { Spółka niepubliczna } \\
(\%)\end{array}$} & & $-0,501$ & & & & $-0,490$ & & $-0,359$ \\
\hline & & $-1,493$ & & & & $-1,452$ & & $-0,998$ \\
\hline \multirow{2}{*}{$\begin{array}{l}\text { Brak zabezpieczenia } \\
(\%)\end{array}$} & & & 0,159 & & & & 0,371 & 0,358 \\
\hline & & & 0,291 & & & & 0,654 & 0,626 \\
\hline \multirow{2}{*}{ Mała emisja (\%) } & & & & $-0,405$ & & & $-0,529$ & $-0,431$ \\
\hline & & & & $-1,239$ & & & $-1,524$ & $-1,188$ \\
\hline \multirow{2}{*}{$\begin{array}{l}\text { Obligacja } \\
\text { długoterminowa (\%) }\end{array}$} & & & & & $-0,167$ & & $-0,368$ & $-0,345$ \\
\hline & & & & & $-0,489$ & & $-1,004$ & $-0,883$ \\
\hline $\mathrm{R}^{\wedge} 2(\%)$ & 0,19 & 1,57 & 0,06 & 1,08 & 0,17 & 1,68 & 1,93 & 2,97 \\
\hline Dopasowany $\mathrm{R}^{\wedge} 2(\%)$ & $-0,53$ & 0,86 & $-0,65$ & 0,38 & $-0,54$ & 0,27 & $-0,20$ & $-0,60$ \\
\hline
\end{tabular}

* Statystycznie różne od 0 na poziomie $10 \%$, ** statystycznie różne od 0 na poziomie 5\%, *** statystycznie różne od 0 na poziomie $1 \%$. Wartości wytłuszczone oznaczają statystyki testowe $t$.

Źródło: opracowanie własne. 
Wprawdzie wyraz wolny równania w większości przypadków okazał się istotny statystycznie, jednak nie udało się wyodrębnić żadnych czynników, które w sposób statystycznie istotny determinowałyby poziom ponadprzeciętnych stóp zwrotu.

\section{Zakończenie}

Anomalie związane z debiutami obligacji korporacyjnych są słabo rozpoznanym obszarem w literaturze naukowej. Poświęcono mu, jak dotychczas, wyraźnie mniejszą uwagę aniżeli giełdom akcji. Nieliczne badania dotyczące rynku amerykańskiego sugerowały występowanie niedoszacowania ceny emisyjnej komercyjnych papierów dłużnych. Niniejszy artykuł stanowił chyba pierwszą próbę zweryfikowania tego, czy podobne zjawisko występuje również w Polsce, a także odpowiedzi na pytanie, jakie czynniki wpływają na jego kształtowanie.

Przeprowadzone obliczenia pozwoliły potwierdzić występowanie na rynku polskim efektu ponadprzeciętnych stóp zwrotu podczas debiutów dłużnych papierów korporacyjnych. Nie udało się jednak wyodrębnić żadnych czynników, które mogłyby determinować poziom niedoszacowania, jak choćby publiczny status spółki czy wielkość emisji. Co więcej, nie udało się potwierdzić obserwacji poczynionych na rynku amerykańskim, dowodzących, że ponadprzeciętne stopy zwrotu są domeną obligacji emitentów pierwszy raz debiutujących na giełdzie. W Polsce w latach 2010-2013 efekt ponadprzeciętnych stóp zwrotu występował z podobnym natężeniem bez względu na wielkość spółki, zapadalność emisji, zabezpieczenie obligacji, publiczny status spółki czy też charakter emisji (typy IBO lub SBO).

Dalsze badania powinny się koncentrować w kilku obszarach. Po pierwsze, zwiększona powinna zostać próba badawcza, zarówno w ujęciu czasowym (emisje, które miały miejsce po publikacji artykułu), jak i geograficznym (emisje z innych rynków). Niezwykle cenne byłoby także rozszerzenie próby na instrumenty rynku niepublicznego, na przykład na podstawie kwotowania dealerów bankowych. Po drugie, wskazane byłoby stworzenie indeksu ryzyka kredytowego lub rynku obligacji korporacyjnych w Polsce. Pozwoliłoby to na większą precyzję obliczeń poprzez uwzględnienie zmian w rynkowej wycenie ryzyka kredytowego w okresie obserwacji. Po trzecie, bardzo wartościowa mogłaby się okazać próba oszacowania wpływu kondycji finansowej (standingu kredytowego) emitentów na zachowanie obligacji po debiucie. Po czwarte, istnieje możliwość, że poszerzenie grona zmiennych jakościowych o nowe elementy (na przykład o zagadnienie płynności obrotu) mogłoby rzucić dodatkowe światło na pytanie o determinanty ponadprzeciętnych stóp zwrotu. 


\section{Literatura}

Allen F., Faulhaber G.R., 1989, Signaling by underpricing in the IPO market, "Journal of Financial Economics", vol. 23, s. 303-323.

Benveniste L.M., Busaba W., Wilhelm W.J., 2002, Information externalities and the role of underwriters in primary equity markets, Journal of Financial Intermediation, vol. 11, s. 61-86.

Benveniste L.M., Spindt P.A., 1989, How investment banks determine the offer price and allocation of new issues, "Journal of Financial Economics", vol. 24, s. 341-361.

Booth J.R., Chua L., 1996, Ownership dispersion, costly information and IPO underpricing, "Journal of Financial Economics", vol. 41, s. 291-310.

Campbell J.Y., Lo A.W., MacKinlay A.C., 1996, The Econometrics of Financial Markets, Princeton University Press, USA.

Carty L., 1996, Is there a Reputation Effect in the US Public Debt Market?, Columbia University working paper.

Chemmanur T.J., Fulghieri P., 1994, Investment bank reputation, information production, and financial intermediation, "Journal of Finance", vol. 49, s. 57-79.

Chemmanur T.J., Paeglis I., 2005, Management quality, certification and initial public offerings, "Journal of Financial Economics", vol. 76, s. 331-368.

Datta S., Iskandar-Datta M., Patel A., 1997, The pricing of initial public offers of corporate straight debt, "Journal of Finance", vol. 52, nr 1, s. 379-396.

Diamond D.W., 1991, Monitoring and reputation - The choice between bank loans and directly placed debt, "Journal of Political Economy", vol. 99, s. 689-721.

Diamond D.W., 1989, Reputation acquisition in debt markets, "Journal of Political Economy", vol. 97, s. $828-862$.

Ederington L.H., 1974, The yield spread on new issues of corporate bonds, "Journal of Finance", vol. 29, s. 1531-1543.

Ellul A., Pagano M., 2006, IPO underpricing and after-market liquidity, "The Review of Financial Studies", vol. 19, $\mathrm{nr}$ 2, s. 381-421.

Fama E., 1998, Market efficiency, long-term returns, and behavioral finance, "Journal of Financial Economics", vol. 49, s. 283-306.

Fenn G.W., 2000, Speed of issuance and the adequacy of disclosure in the 144 a high-yield debt market, "Journal of Financial Economics", vol. 56, s. 383-405.

Fung W.K.H., Rudd A., 1986, Pricing new corporate bond issues: An analysis of issue cost and seasoning effects, "Journal of Finance", vol. 3, s. 633-643.

Gorton G., 1996, Reputation formation in early bank note markets, "Journal of Political Economy", vol. 104, s. 346-397.

Grinblatt M., Hwang C.Y., 1989, Signaling and the pricing of unseasoned new issues, "Journal of Finance", vol. 44, s. 393-420.

Helwege J., Kleiman P., 1998, The pricing of high-yield debt IPOs, "The Journal of Fixed Income", vol. 8, s. 61-68.

Hughes P.J., Thakor A.V., 1992, Litigation risk, intermediation risk and the underpricing of initial public offerings, "Review of Financial Studies", vol. 4, 709-742.

Jenkinson T., Ljungqvist A., 2001, Going Public: The Theory and Evidence on How Firms Raise Equity Finance, Oxford University Press, New York.

Kelly N.C., Helwege J., Warga A., 2007, Underpricing in the corporate bond market, "Review of Financial Studies", vol. 20, nr 6, s. 2021-2046.

Kothari S., Warner J., 1997, Measuring long-horizon security price performance, "Journal of Financial Economics", vol. 43, s. 301-339.

Kothari S., Warner J., 2006, Econometrics of event studies, [w:] E. Eckbo (red.), Handbook of Empirical Corporate Finance, Elsevier-North-Holland, Amsterdam. 
Kozhanov I., Ogden J.P., 2012, The Pricing and Performance of New Corporate Bonds: Sorting Out Underpricing and Liquidity Effects, working paper.

Kozhanov I., Ogden J.P., Vaghefi F., 2011, The Pricing and Performance of New Corporate Bonds: TRACE-Era Evidence, working paper.

Lindvall J., 1977, New issue corporate bonds, seasoned market efficiency and yield spreads, "Journal of Finance", vol. 32, s. 1057-1067.

MacKinlay A.C., 1997, Event studies in economics and finance, "Journal of Economic Literature", vol. 35 , nr 1, s. 13-39.

McKenzie C.R., Takaoka S., 2008, Mispricing in the Japanese Corporate Bond Market, working paper. Ritter J.R., 1998, Initial Public Offerings, Warren Gorham \& Lamont Handbook of Modern Finance, USA.

Rock K., 1986, Why new issues are underpriced, "Journal of Financial Economics", vol. 15, s. 187-212.

Sherman A.E., Titman S., 2002, Building the IPO order book: Underpricing and participation limits with costly information, "Journal of Financial Economics", vol. 65, s. 3-29.

Sorenson E.H., 1982, On the seasoning process of new bonds: Some are more seasoned than others, "Journal of Financial and Quantitative Analysis", vol. 42, s. 195-208.

Takaoka S., McKenzie C.R., 2006, The impact of bank entry in the Japanese corporate bond underwriting market, "Journal of Banking \& Finance", vol. 30, nr 1, s. 59-83.

Wasserfallen W., Wydler D., 1988, Underpricing of newly issued bonds: Evidence from the Swiss capital market, "Journal of Finance", vol. 43, s. 1177-1191.

Weinstein M.I., 1978, The seasoning process of new corporate bond issues, "Journal of Finance", vol. 33, s. 1343-1354.

Welch I., 1989, Seasoned offerings, imitation costs, and the underpricing of IPOs, "Journal of Finance", vol. 44, s. 421-449.

Zaremba A., 2014, Underpricing of newly issued corporate bonds in CEE markets, "European Journal of Economics and Management", vol. 1, nr 1, s. 6-16.

Zaremba A., Kamiński K., 2011, IPOs - not so much money on the table. The cost compensation hypothesis, "Argumenta Oeconomica, vol. 1, nr 26, s. 149-175.

Zaremba, A., Szyszka A., 2014, Is the Abnormal Post-IPO Underperformance Really Abnormal? The Evidence from CEE Emerging Markets, working paper, http://ssrn.com/abstract=2487926 lub http://dx.doi.org/10.2139/ssrn.2487926 [dostęp: 17.12.2014].

\section{UNDERPRICING OF INITIAL BOND OFFERINGS: EVIDENCE FROM THE CATALYST MARKET}

Summary: The aim of this paper is to investigate the undepricing phenomenon of newly issued corporate bonds in the Polish market and its determinants. The study is composed of three parts. The study is based on a filtered sample of 142 corporate bonds issued between March 2010 and August 2013 and listed in Poland. The paper ends with conclusions and suggestions for further research. The study makes two crucial contributions to the relatively modest literature on initial bond offering mispricing: it attempts to verify whether the IBO mispricing is present also in the emerging markets and it tries to identify which factors influence the size of the mispricing. The performed analysis allows to confirm the existence of the uderpricing effect of newly issued bonds in the Polish market. However, it is not possible to indicate any specific factors which have particularly influenced the size of the underpricing.

Keywords: corporate bonds, undepricing anomaly, new issues, financial market efficiency, Catalyst. 